\title{
Transmissible spongiform encephalopathies
}

Transmissible spongiform encephalopathies (TSE) are a group of transmissible diseases characterised by subacute degeneration of the brain. Microcystosis of neurones and neuropil in the grey matter results in a sponge-like (spongiform) appearance in histological sections. There is loss of neurones, a proliferation of fibrous astrocytes (astrogliosis) but none of the characteristic changes of infection or inflammation (hence the term encephalopathy). The disease progresses inexorably to death.

The first TSE described was scrapie in sheep, in 1738. However, its infectious nature was not recognised until 1938 when more than 1500 sheep developed scrapie following the use of a louping illness vaccine prepared from formalin-inactivated sheep lymphoid tissue. ${ }^{1}$ The term scrapie was used to describe the repeated rubbing or scraping behaviour of the sheep against fences and walls. Since then, naturally occurring TSE has been described in a large variety of animal species (table I). The TSE of man are Kuru, found in the mountainous Fore region of Papua New Guinea, Creutzfeldt-Jakob disease (CJD) which is the commonest human TSE (c. $1 / 10^{6}$ population), Gerstmann-Sträussler-Scheinker disease (GSS) and fatal familial insomnia (FFI).

\section{The agent}

The nature of the transmissible agent of TSE has been a source of considerable discussion for a decade or more. ${ }^{2}$ Some consider that TSE is a result of infection with a slow virus or virus-like agent (virino). Others propose that the infection is due to small proteinaceous infection (prion) particles. ${ }^{3}$ Although virus-like structures (c. 10-12 nm diameter) have been described recently from brains of cases of scrapie ${ }^{4}$ and $\mathrm{CJD},{ }^{5}$ the prion hypothesis has gained wide acceptance. The agent is highly resistant to physical and chemical treatments that would normally inactivate DNA and RNA (table II), including ionising radiation, aldehyde disinfectants and nuclease enzymes.

In cases of TSE, the brain contains amyloid plaques composed of a protein with characteristic fibrillar ultrastructural morphology. This protein co-purifies with scrapie infectivity, is highly hydrophobic ${ }^{6}$ and tends to aggregate to form fibrillar structures called prion rods (figure). Proteolytic digestion results in a highly enriched protein fraction with a concentration proportional to the infectivity titre. The protein, termed prion protein $(\operatorname{PrP})$, has an $\mathrm{M}_{\mathrm{r}}$ of $27-30 \mathrm{kDa}$ and is now often referred to as $\operatorname{PrP} 27-30 .^{7}$ In fact, it is derived by proteolytic digestion from a larger protein
(33-35 kDa) which is designated $\operatorname{PrP}^{\mathrm{se}}$. The protein sequence has been determined and a DNA sequence derived. This gene (PRPN) sequence, located on the short arm of chromosome 20 in man and on chromo-

Table I. Naturally occurring TSE of man and other animals

\begin{tabular}{|c|c|c|}
\hline Disease & Species & $\begin{array}{c}\text { First } \\
\text { described }\end{array}$ \\
\hline Kuru & Man & 1957 \\
\hline $\begin{array}{l}\text { Creutzfeldt-Jakob } \\
\text { disease }\end{array}$ & Man & 1920 \\
\hline $\begin{array}{l}\text { Gerstmann-Sträussler- } \\
\text { Scheinker disease }\end{array}$ & Man & 1936 \\
\hline Fatal familial insomnia & Man & 1992 \\
\hline Scrapie & Sheep, goats, moufflon & 1738 \\
\hline $\begin{array}{l}\text { Transmissible mink } \\
\text { encephalopathy }\end{array}$ & Mink & 1964 \\
\hline $\begin{array}{l}\text { Chronic wasting } \\
\text { disease }\end{array}$ & Mule deer, elk & 1980 \\
\hline $\begin{array}{l}\text { Bovine spongiform } \\
\text { encephalopathy (BSE) } \\
\text { (Downers) }\end{array}$ & Cattle & $\begin{array}{c}1986 \\
(? 1965)\end{array}$ \\
\hline $\begin{array}{l}\text { Exotic ungulate } \\
\text { encephalopathy }\end{array}$ & $\begin{array}{l}\text { Nyala, kudu, gemsbok, } \\
\text { oryx }\end{array}$ & 1986 \\
\hline $\begin{array}{l}\text { Feline spongiform } \\
\text { encephalopathy }\end{array}$ & Cats (puma, cheetah) & 1990 \\
\hline Not named yet & Ostrich & 1991 \\
\hline
\end{tabular}

Table II. Physical properties and physicochemical inactivation

\begin{tabular}{|c|c|}
\hline Size & Filterable through $25-50 \mathrm{~nm}$ pores size \\
\hline Heat stability & $\begin{array}{l}\text { Stable at } 90^{\circ} \mathrm{C} \text { for } 30 \mathrm{~min} \text {; inactivated } \\
\text { at } 121^{\circ} \mathrm{C}, 15 \mathrm{psi} \text { for } 1 \mathrm{~h}\end{array}$ \\
\hline $\mathbf{M}_{\mathrm{r}}$ & $\begin{array}{l}\text { Target size by ionising radiation } \\
64-150 \mathrm{kDa} \\
\text { by Gel filtration } \leqslant 50 \mathrm{kDa}\end{array}$ \\
\hline Density range & $1.08-1.30 \mathrm{~g} / \mathrm{ml}$ \\
\hline Resistant to: & $\begin{array}{l}\text { Aldehydes (including formaldehyde, } \\
\text { glutaraldehyde) } \\
\text { Nucleases (RNAase, DNAase) } \\
\text { Heat }\left(80^{\circ} \mathrm{C}\right) \\
\text { UV and ionising radiation } \\
\text { Mild organic solvents (ethanol, xylene) } \\
\text { Weak chaotropes } \\
\text { Non-ionic detergents }\end{array}$ \\
\hline Moderately resistant to: & $\begin{array}{l}\text { Ether } \\
\text { Acetone } \\
\text { Ethylene oxide }\end{array}$ \\
\hline Inactivated by: & $\begin{array}{l}\text { Autoclaving }\left(121^{\circ} \mathrm{C}, 15 \mathrm{psi} \text { for } 1 \mathrm{~h} \text { ) }\right. \\
\text { Proteases (pronase, trypsin) } \\
\text { Denaturing ionic detergents (SDS) } \\
\text { Strong chaotropes (trichloracetate, } \\
\text { thiocyanate, urea) } \\
\text { Strong organic solvents (phenol, } \\
\text { chloroform) } \\
\text { Strong oxidising agents (periodate, } \\
\text { hypochlorite } 0 \cdot 5 \% \text { ) } \\
\mathrm{NaOH}(1 \mathrm{M})\end{array}$ \\
\hline
\end{tabular}




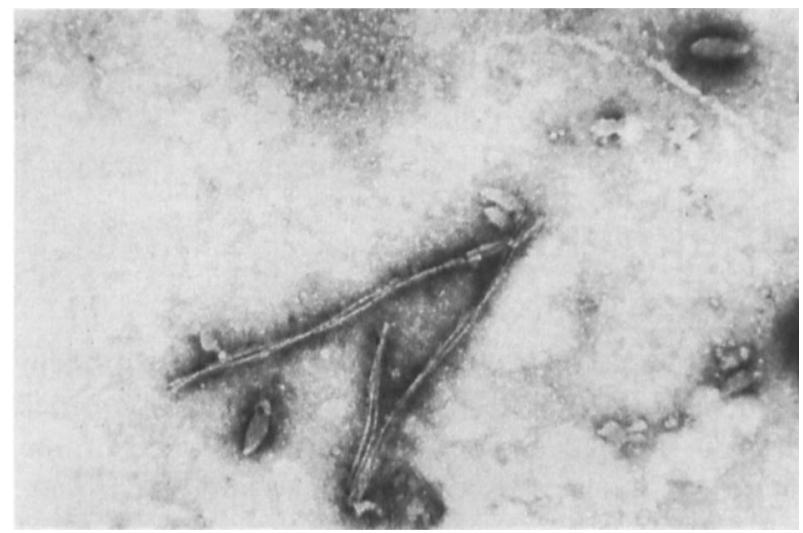

Figure. Negatively stained electronmicrograph showing fibrillar prion rods. Magnification $\times 24000$ (Crown Copyright: reprinted from Colour Atlas of Paediatric Infectious Diseases: Wolfe).

some 2 in mice $(P r n-p)$, encodes a protein $\left(\operatorname{PrP}^{c}\right)$ found normally in the brain; levels of $\operatorname{PrP}^{c}$ mRNA in normal and scrapie-infected hamster brain are equivalent. ${ }^{8}$ However, normal $\operatorname{PrP}^{c}$ is completely digestible by proteolytic enzymes whereas $\operatorname{PrP}^{\text {sc }}$ is resistant to digestion. PrPse is found only in brains affected by TSE, and antibody raised in hamsters against $\operatorname{PrP}^{s c}$ specifically stains the amyloid plaques in CJD, GSS and scrapie. ${ }^{9}$

Further evidence for the role of $\operatorname{PrP}^{\text {sc }}$ in TSE comes from experiments with transgenic mice. Mice in which the Prn-p gene has been ablated cannot be infected by scrapie and the incubation period is prolonged in heterozygotes. ${ }^{10}$ Both proteins have similar aminoacid sequences and it is thought that $\operatorname{PrP}^{s c}$ is a conformational isomer of $\operatorname{PrP}^{\mathrm{c}}$. $\mathrm{PrP}^{s c}$ is insoluble, protease-resistant and has a high $\beta$-sheet content $; \operatorname{PrP}^{c}$ is soluble and protease-sensitive with a high $\alpha$-helical content. Furthermore, it is hypothesised that when inoculated into brain, $\operatorname{PrP}^{s c}$ acts as a nidus for the conversion of $\operatorname{PrP}^{c}$ to $\mathrm{PrP}^{\mathrm{se}}$. The more closely related the amino-acid sequences the more quickly the change occurs, which might explain the existence of different "strains" of scrapie with differing incubation periods. Recently, this conversion of $\operatorname{PrP}^{\mathrm{c}}$ to $\mathrm{PrP}^{\mathrm{se}}$ "catalysed" by $\mathrm{PrP}^{\mathrm{sc}}$ has been observed in a cell-free in-vitro system. ${ }^{11}$ The prion hypothesis does not explain completely every facet of TSE; for example, amphotericin B prolongs the scrapie incubation period, delays the accumulation of $\operatorname{PrP}^{\mathrm{sc}}$ but does not affect scrapie replication. ${ }^{12}$ Nevertheless, the prion hypothesis is now the most likely explanation for TSE.

\section{Epidemiology and transmission}

CJD is found world-wide and is the commonest TSE of man with an incidence in the UK of $0 \cdot 4-0.89 / 10^{6}$ population. Most cases are sporadic, but c. $10 \%$ are familial, usually associated with point mutations in PRPN. An increasing proportion appear to be iatrogenic. ${ }^{13}$ The mode of spread of sporadic CJD is unknown. Iatrogenic spread may occur by direct inoculation into the central nervous system via surgical procedures, particularly when involving tissue transfer, or by peripheral inoculation, for example, growth hormone and pituitary gonadotrophin injections or accidentally at autopsy. When CJD material is introduced into the brain by stereotactic surgery, dura mater implants or corneal transplants, the incubation period is short, of the order of months. In contrast, peripheral inoculation results in incubation periods of 4-30 years. There has been recent evidence suggesting transplacental transmission of CJD. ${ }^{14}$

The incidence of GSS is $<2 / 10^{8}$ population. All reported cases come from the northern hemisphere and most cases are familial. The remainder are sporadic. Four different clinical variants of GSS exist ${ }^{3}$ and each is associated with a different point mutation in PRPN, at codons $102,117,198$ or 217 . FFI is inherited as an autosomal dominant in three Italian families.

Although cases of Kuru still occur in Papua New Guinea, no cases have occurred in those born since cannibalism ceased in 1960, indicating that the incubation period can be as long as 34 years. Most evidence implicates ritual cannibalism and thus oral acquisition in Kuru. The youngest child to present with Kuru was 5 years old, suggesting this time period as the shortest incubation period for orally acquired TSE.

\section{The diseases}

The presentation of sporadic and iatrogenic CJD differs considerably. For example, iatrogenic CJD invariably presents with cerebellar signs, whereas only a third of sporadic CJD cases present in this way. ${ }^{13}$ Mental deterioration is common in sporadic CJD but not in iatrogenic CJD. Both diseases progress inexorably to death with visual and oculomotor dysfunction, myoclonus and pyramidal and extrapyramidal signs over 12-24 months.

GSS has four different presentations according to which codon is altered. Point mutations at codon 102 result in ataxia, at codon 117 in dementia and pseudobulbar signs, at codon 198 in ataxia, dementia and Parkinsonism, and at codon 217 in dementia alone. The prodromal features of headache and joint pain in Kuru are followed 6-12 weeks later by cerebellar signs including difficulty in walking. Death usually occurs within 12 months and is preceded by dementia. ${ }^{15}$

\section{Species barriers?}

With the emergence of BSE there has been great interest in the possibility of TSE crossing species barriers and, in particular, affecting man. ${ }^{16} \mathrm{CJD}$ has been transmitted by intracerebral inoculation to apes, monkeys, marmosets, goats, cats, rats and mice. Kuru has been similarly transmitted to apes, monkeys and cats, and orally transmitted to non-human primates. ${ }^{17}$ GSS has been transmitted by intracerebral inoculation to monkeys and marmosets. Thus, it appears that the 
human TSE can cross species barriers even by oral inoculation. The incubation period seems to lengthen with greater evolutionary distance between species.

BSE has been transmitted by intracerebral, intravenous or intraperitoneal inoculation to cattle, pigs, marmosets, goats, sheep and mice. ${ }^{16}$ Oral transmission of BSE has occurred after a prolonged incubation

\section{References}

1. Gordon WS. Advances in veterinary research. Vet Res 1946; 58 : 516-520.

2. Liberski PP. Subacute spongiform encephalopathies-the transmissible brain amyloidoses: a comparison with nontransmissible brain amyloidoses of Alzheimer type. J Comp Pathol 1993; 109: 103-127.

3. Prusiner S. Prion diseases of humans and animals. $J R$ Coll Physicians Lond 1994; 28 Suppl: 1-30.

4. Özel M, Diringer H. Small virus-like structure in fractions from scrapie hamster brain. Lancet 1994; 343: 894-895.

5. Özel M, Xi Y-G, Baldauf E, Diringer H, Pocchiari M. Small virus-like structure in brains from cases of sporadic and familial Creutzfeldt-Jakob disease. Lancet 1994; 344: 923-924.

6. Prusiner SB, McKinley MP, Groth DF et al. Scrapie agent contains a hydrophobic protein. Proc Natl Acad Sci USA $1981 ; 78: 6675-6679$.

7. McKinley MP, Bolton DC, Prusiner SB. A protease-resistant protein is a structural component of the scrapie prion. Cell $1983 ; 35: 57-62$.

8. Oesch B, Westaway D, Wälchli M et al. A cellular gene encodes scrapie PrP 27-30 protein. Cell 1985; 40: 735-746.

9. Snow AD, Kisilevsky R, Wilmer J, Prusiner SB, DeArmond SJ. Sulphated glycosaminoglycans in amyloid plaques of prion diseases. Acta Neuropathol 1989; 77: 337-342.

10. Prusiner SB, Groth D, Serban A et al. Ablation of the prion protein $(\operatorname{PrP})$ gene in mice prevents scrapie and facilitates period (2-3 years) to mice, goats, sheep ${ }^{\mathbf{1 6}}$ and a marmoset. ${ }^{3}$ It is not known whether BSE poses a risk to man, and reports linking CJD to BSE do not necessarily prove an association. ${ }^{18}$

C. A. Hart

Department of Medical Microbiology, University of Liverpool, P.O. Box 147, Liverpool L69 3BX, UK.

production of anti-PrP antibodies. Proc Natl Acad Sci USA 1993; 90 : 10608-10612.

11. Kocisko DA, Come JH, Priola SA et al. Cell-free formation of protease-resistant prion protein. Nature 1994; 370: $471-474$

12. Xi YG, Ingrosso L, Ladogana A, Masullo C, Pocchiari $M$. Amphotericin B treatment dissociates in vivo replication of the scrapie agent from PrP accumulation. Nature 1992; 356: 598-601.

13. Brown P, Preece MA, Will RG. "Friendly fire" in medicine: hormones, homografts, and Creutzfeldt-Jakob disease. Lancet 1992; 340: 24-27.

14. Tamai Y, Kojima H, Kitajima R et al. Demonstration of the transmissible agent in tissue from a pregnant woman with Creutzfeldt-Jakob disease. $N$ Engl $J$ Med 1992; 327: 649.

15. Gajdusek DC, Zigas V. Clinical, pathological and epidemiological study of an acute progressive degenerative disease of the central nervous system among natives of the Eastern Highlands of New Guinea. Am J Med 1959; 26: 442-469.

16. Lacey RW. Mad cow disease: a history of BSE in Britain. Jersey, Cypsela Publications Ltd. 1994.

17. Gibbs CJ, Amyx HL, Bacote A, Masters CL, Gajdusek DC. Oral transmission of Kuru, Creutzfeldt-Jakob disease, and scrapie to nonhuman primates. J Infect Dis 1980; 142: 205-208.

18. Davies PTG, Jahfar S, Ferguson IT, Windl O. CreutzfeldtJakob disease in individuals occupationally exposed to BSE. Lancet 1993; 342 : 680. 